\title{
Use of bilateral groin flaps in the closure of defects of the perineum: A case report
}

\author{
Chenicheri Balakrishnan MD, Justin D Klein MD, Christopher Vashi MD
}

\author{
C Balakrishnan, JD Klein, C Vashi. Use of bilateral groin flaps \\ in the closure of defects of the perineum: A case report. Can J \\ Plast Surg 2006;14(3):179-180.
}

\begin{abstract}
Reconstruction of perineal and groin defects is a challenging problem. Commonly used methods of reconstruction include skin grafts and local flaps. The groin flap is a vascularized axial flap based on the superficial circumflex iliac artery arising from the femoral artery just below the inguinal ligament. Due to the location, the donor defect can usually be closed primarily, leaving an acceptable scar. The use of bilateral groin flaps for coverage of defects of the anterior perineum following excision of condylomas is reported.
\end{abstract}

Key Words: Groin defects

\section{Pose de lambeaux inguinaux bilatéraux pour le comblement de pertes de substance du périnée : exposé de cas}

\begin{abstract}
La reconstruction du périnée et de l'aine pour perte de substance est très difficile à réaliser sur le plan technique. Les méthodes courantes de reconstruction comprennent les lambeaux cutanés et les lambeaux de voisinage. Le lambeau inguinal est un lambeau axial, vascularisé, sis sur l'artère circonflexe iliaque superficielle, qui naît de l'artère fémorale située juste sous le ligament inguinal. Compte tenu de son emplacement, la zone donneuse peut généralement être refermée en cours d'intervention, en laissant une cicatrice acceptable. Voici donc la description de la pose de lambeaux inguinaux bilatéraux pour le comblement de perte de substance du périnée antérieur après l'ablation de condylomes.
\end{abstract}

$\mathrm{R}$ econstruction of soft tissue defects of the perineum is not Reasy. These defects are usually from excision of hidradenitis or necrotizing fasciitis. Common practice is to skin graft the area after obtaining adequate granulation of the wound bed. These skin grafts are difficult to manage due to fecal soiling. To prevent shearing, bolster dressing and even the use of vacuumassisted closures are used with success in difficult areas; however, it is usually difficult to maintain the seal for the vacuum device over the perineum. Commonly used local flaps include tensor fascia lata, gracilis, rectus abdominis, rectus femoris, sartorius and pudendal artery thigh flaps. Although free tissue transfer can be used as a single-stage procedure, bilateral defects are technically challenging. Flaps from the abdomen could be fashioned to close these defects based on the musculocutaneous perforators. We report the use of bilateral groin flaps for the reconstruction of defects following excision of condylomas involving the anterior perineum.

\section{CASE PRESENTATION}

A 39-year-old man presented to the urology department with significant growth of his groin for two years (Figure 1). These lesions were progressive and bled at times. A biopsy was reported as a verrucous lesion of possible viral etiology with no evidence of malignancy. He underwent wide excision of the lesion. The defect involved the suprapubic area and the anterior perineum (Figure 2). The lower abdominal skin was advanced to close the suprapubic area, and the defects of the groin area were closed by transposing bilateral groin flaps (Figure 3). The donor defect was closed primarily along the groin crease.

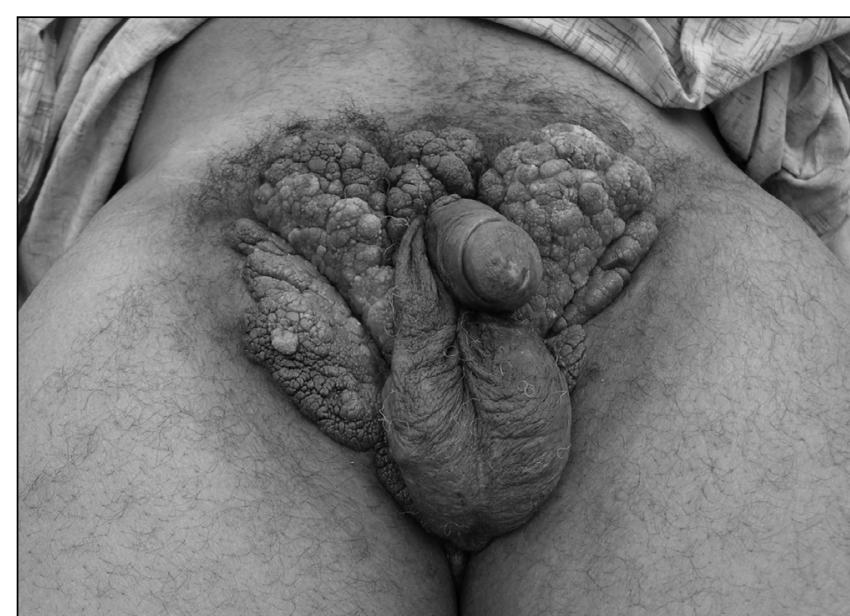

Figure 1) Condyloma of the perineum

\section{DISCUSSION}

Skin flaps fulfil the functional and cosmetic requirements for wound coverage. The bulk of the flap usually fills the contour defect, and the skin and subcutaneous tissue provide a stable coverage of the defect. Other options include skin grafts and the use of vacuum-assisted closure. Wound care to provide a good, granulating wound bed can be obtained by repeated dressing changes or with the vacuum-assisted closure method. Skin grafts require immobilization of the area 


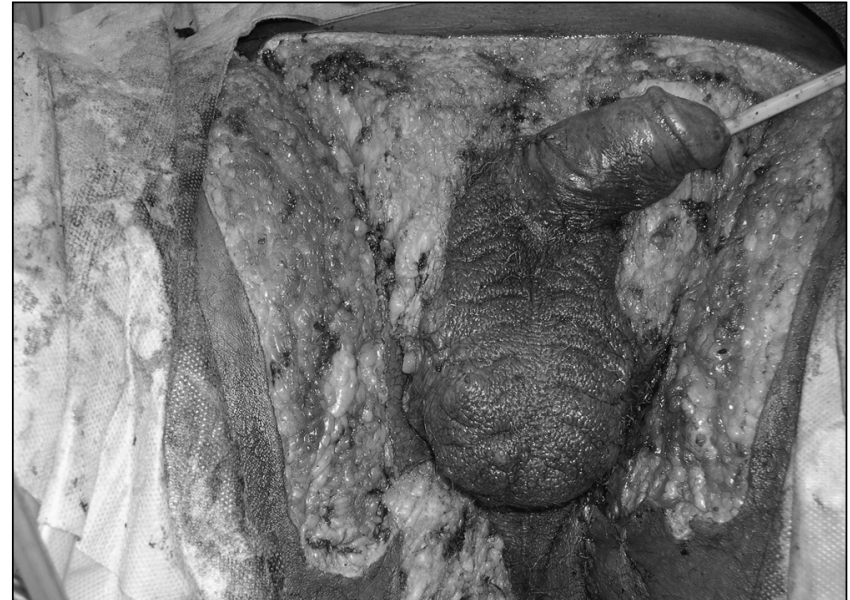

Figure 2) Soft tissue defect following excision

to prevent shearing. Due to the shape of the defect and the irregular contour of the perineum and groin, it is usually difficult to obtain a good seal for vacuum-assisted closure. To prevent fecal soiling of the skin grafts, diverting colostomy or rectal tubes can be used. Although skin grafts provide a good method of wound closure, they tend to contract and break down easily.

The groin flap is an axial pattern flap based on the superficial circumflex iliac artery and the superficial venous network of the groin area (1). It is considered to be a type A fasciocutaneous flap because it includes the fascia of the sartorius muscle and Scarpa's fascia (2). The superficial circumflex artery commonly arises from the femoral artery and, in approximately $50 \%$ of cases, there will be a common trunk with the superficial inferior epigastric artery. The point of origin lies approximately $3 \mathrm{~cm}$ below the mid-inguinal point. The superficial iliac artery passes through the deep fascia into the subcutaneous tissue lateral to the fossa ovalis at or close to the lateral border of the sartorius muscle. It anastomoses with the branches of superficial epigastric artery and the lateral femoral circumflex arterial system. The flap is raised laterally to the femoral vessels, where the skin is usually devoid of hair. Because the flap has a retrograde blood flow, edema is a usual problem. Furthermore, because the perineal skin is lax and devoid of much fat, the flap is usually bulky and may require revision.

The pedicle flap principle and the knowledge of blood supply of the various angiosomes forms the fundamental basis for the development of reconstructive surgery. The medially based transverse abdominal flap, which is located proximally to the groin flap, can reach the groin, and the anterior thigh region has the axial blood supply from the perforating branches of the epigastric arcade (3). Although the groin flap was first reported

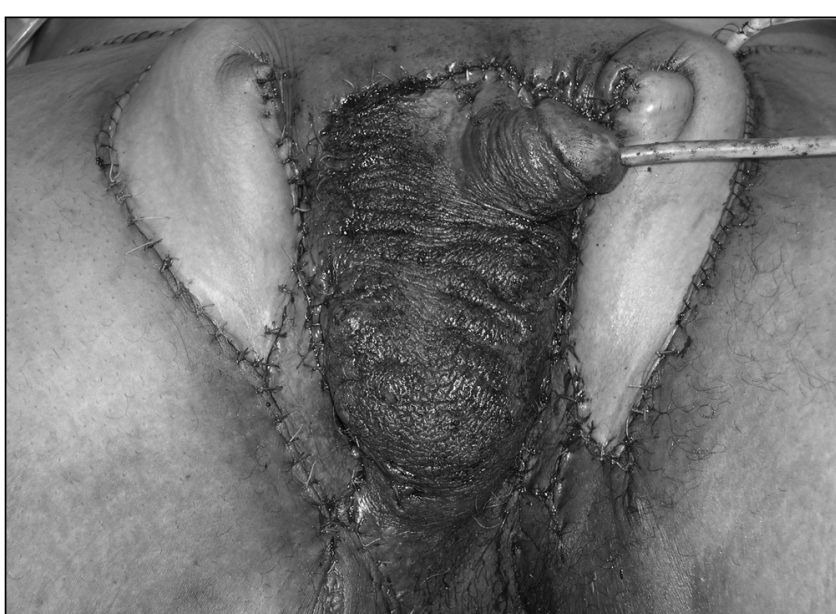

Figure 3) Bilateral groin flap in place

as a pedicled skin flap, it has been used as a free flap by O'Brien et al (4) and modified as the free iliac flap with a lateral skin island by Acland (5). It is used regularly by many reconstructive surgeons for covering soft tissue defects of the hand as a pedicled flap. Being an axial pattern flap, the groin flap can reliably be raised with good length to breadth ratio. The donor site scar lies in a cosmetically advantageous position. The venous drainage is through a superficial set, which drains into the saphenous system. The deep set of venae comitantes are a less important route of drainage, and may also join the saphenofemoral junction or may pass deeply beneath the femoral artery to enter the femoral vein.

In the present patient, excision of the lesion left a defect on both sides, which required closure to prevent both scarring and abduction of the hip. The defect was closed using bilateral groin flaps. Although this may become bulky due to fat deposition in later life, the groin flap has provided excellent wound coverage in this patient.

\section{REFERENCES}

1. McGregor IA, Jackson IT. The groin flap. Br J Plast Surg 1972;25:3-16.

2. Cormack GC, Lamberty BC. A classification of fascio-cutaneous flaps according to their patterns of vascularisation. Br J Plast Surg 1984;37:80-7.

3. Brown RG, Vasconez LO, Jurkiewicz MJ. Transverse abdominal flaps and the deep epigastric arcade. Plast Reconstr Surg 1975;55:416-21.

4. O'Brien BM, MacLeod AM, Hayhurst JW, Morrison WA. Successful transfer of a large island from the groin to the foot by microvascular anastomosis. Plast Reconstr Surg 1973;52:271-8.

5. Acland RD. The free iliac flap: A lateral modification of the free groin flap. Plast Reconstr Surg 1979;64:30-6. 